\title{
Evaluation Expression COX-2 in Prostatic Carcinoma by PCR and Immunohistochemistry and Its Relationship with Gleason Score
}

\author{
Maryam Ghiasi, Hedieh Moradi Tabriz, Elham Nazar
}

Department of Pathology, Tehran University of Medical Sciences, Tehran, Iran.

\begin{abstract}
Introduction: Prostate cancer is among the most common malignancies. Despite the high prevalence and importance of prostate cancer, the molecular mechanisms underlying its development and progression remain poorly understood. Materials and Methods: This cross sectional study was conducted on 50 cases of prostatic carcinoma with different Gleason score referred to Sina hospital in Tehran in Iran in 2016. The gene expression was assessed by using the immunohistochemistry staining and PCR technique. Result: The presence of neoplasia on prostatic biopsy induced strong staining and increased in mRNA level of COX-2 expression when compared to normal tissue ( $\mathrm{P}-$ Value $>0.05$ ). The expression is not well associated with different Gleason grades of prostatic carcinoma. Conclusion: The expression of COX-2 protein by immunohistochemistry staining and PCR technique in our study offers the valuable diagnostic information. Thus, we think this marker might be studied in larger series of patients for its further validation as diagnostic factor in prostate biopsies.
\end{abstract}

Keywords: COX-2- prostate- carcinoma- Gleason score

Asian Pac J Cancer Biol, 6 (2), 105-109

\section{Introduction}

Prostatic carcinoma (PC) is among the most common malignancies [1]. Most studies reflect the etiology of PC is multifactorial. Although, current screening has been realized, the pathogenesis of prostate cancer are still unclear [2]. Cyclooxygenase-1 (COX-1) and cyclooxygenase-2 (COX-2) are the two isoforms of cyclooxygenase, which transform arachidonic acid (AA) into some eicosanoids such as prostaglandin, thromboxane, and prostacyclin which contribute in several normal physiologic processes and inflammation [3]. COX-2 is an inducer of angiogenesis of new blood vessels [4]. COX-2, on the other hand, is an inducible isoform, quickly induced by growth factors, tumor promoters, oncogenes and carcinogens [5]. So, up-regulation of COX-2 is related with carcinogenesis in multiple organ systems such as the large bowel, lung, breast, and prostate [6]. Epidemiological studies have revealed a reduced risk of prostate cancer between men who recurrently take aspirin or other non-steroidal anti-inflammatory drugs
Submission Date: 02/03/2021Ａcceptance Date: 04/15/2021
(NSAIDs) [7]. COX-2 expression in prostate core needle biopsies may display significance in preprostatectomy prognosis [8]. COX-2 is expressed in PC; however, expression is not related to the presence of inflammatory cells infiltration [9]. The aim of this work is to find out the diagnostic value of the mentioned molecule in the core needle biopsies of patients with PC. Other goals are to establish its relation with Gleason score which is known as prognostic factors.

\section{Materials and Methods}

A total of 50 PC on core needle biopsy were reviewed for pathology in Sina hospital affiliated Tehran University of Medical Sciences. The average patients' age was 60 years. All data were collected from pathology reports and patient's record archives. Cases with incomplete information were excluded. Exclusion criteria were atypical adenomatous hyperplasia or

\footnotetext{
Corresponding Author:

Dr. Elham Nazar

Department of Pathology, Tehran University of Medical Sciences, Tehran, Iran

Email: elhamnazar@yahoo.com
} 
metastatic involvement. Also, 10 normal prostatic core needle biopsies were selected. All slides were reassessed by an expert pathologist who was unaware of the patients' history. After diagnosis confirmation based on morphology, appropriate blocks of each sample were selected. The specimens were classified according to the International Society of Urological Pathology (ISUP) consensus conference in 2014 [10].

\section{Immunohistochemistry staining}

Paraffin blocks were cut with 2 micrometer thickness. Slides were coated with Poly-L-lysine and then deparaffined and rehydrated. Immunohistochemistry (IHC) staining for the detection of COX-2 expression was performed on one representative slide per tumor which exhibited a maximum of tumoral tissue and on normal tissue for comparison. Primary antibody (Polyclonal rabbit anti-human COX-2, Dako) with a dilution of $1 / 250$ was performed according to the manufacturer's protocol for COX-2 staining. Hematoxylin was used to stain the background. COX-2 immunolabelling was intracytoplasmic and perinuclear considered as positive and base of intensity was graded weak: +1 , moderate: +2 , and strong: +3 [11].

\section{Molecular study}

The expression of COX2 was studied by semiquantitative PCR. The PCR amplification reaction was carried out by AccuPower GreenStar qPCR Premix (Bioneer, Korea) using Stratagene Mx3005PqPCR system (Agilent Technologies, CA, USA). The thermal profile reaction used was 5 minutes at $95^{\circ} \mathrm{C}$ for 1 cycle, followed by 40 cycles at $94^{\circ} \mathrm{C}$ for 15 seconds, $55^{\circ} \mathrm{C}$ for 30 seconds and $72^{\circ} \mathrm{C}$ for 30 seconds. Beta-Actin was amplified as internal control. Arrays were performed and the values were obtained for the threshold cycle $(\mathrm{Ct})$ for each gene and normalized using the housekeeping gene (Beta-Actin) on the same array. The change $(\Delta \mathrm{Ct})$ between the genes of neoplastic and normal tissue and controls was determined. The fold-change was determined using the formula, fold-change $=2\left({ }^{-\Delta \Delta C t}\right)$. The resulting values were reported as fold-change; only genes showing two-fold or greater change were considered. The study endpoint was to first compare gene expressions in PC and normal prostatic tissue. The sequences of the primers and the respective conditions used for COX2 were according to Table 1 .

This study is cross-sectional and investigated the association of COX-2 expression by IHC staining and PCR and Gleason score of PC on core needle biopsy specimens in Sina hospital in 2016.

\section{Statistical Analysis}

For statistical analysis, results were presented as mean \pm standard deviation (SD) for quantitative variables and were summarized by absolute frequencies and percentages for categorical variables. Quantitative variables were also compared with T-test or Mann-Whitney U test. The association between the variables was examined using the Pearson's or Spearman's correlation test. For the statistical analysis, the statistical software SPSS version 16 for windows (SPSS Inc., Chicago, IL) was used. P values of 0.05 or less were considered statistically significant.

\section{Results}

The database query returned 60 patients. We excluded 10 patients with inadequate specimen. The remaining 50 patients were evaluated who mean age of 60 years.

COX-2 immunolabelling was intracytoplasmic and, in some neoplastic cells, perinuclear; it was demonstrated in neoplastic cells and its intensity was usually mild to moderate. In contrast, all normal tissues showed no staining (Figure 1).

Mean levels of COX-2 mRNA were 2.3-fold higher in PC tissue $(\mathrm{n}=50)$ compared with the paired benign tissue which was similar to other study (1.8-3.4 fold) (Table 2) (12).

The COX-2 gene expression in PC and benign tissue by PCR are shown in Figure 2.

There was no significant difference in the mRNA level of COX-2 gene between the cancer tissues with different Gleason score (P-Value: $>0.5$ ). However, the mRNA level of COX-2 gene was considerably higher in the cancer tissue as compared to the normal samples. In other word, the presence of PC induced a 2.3-fold

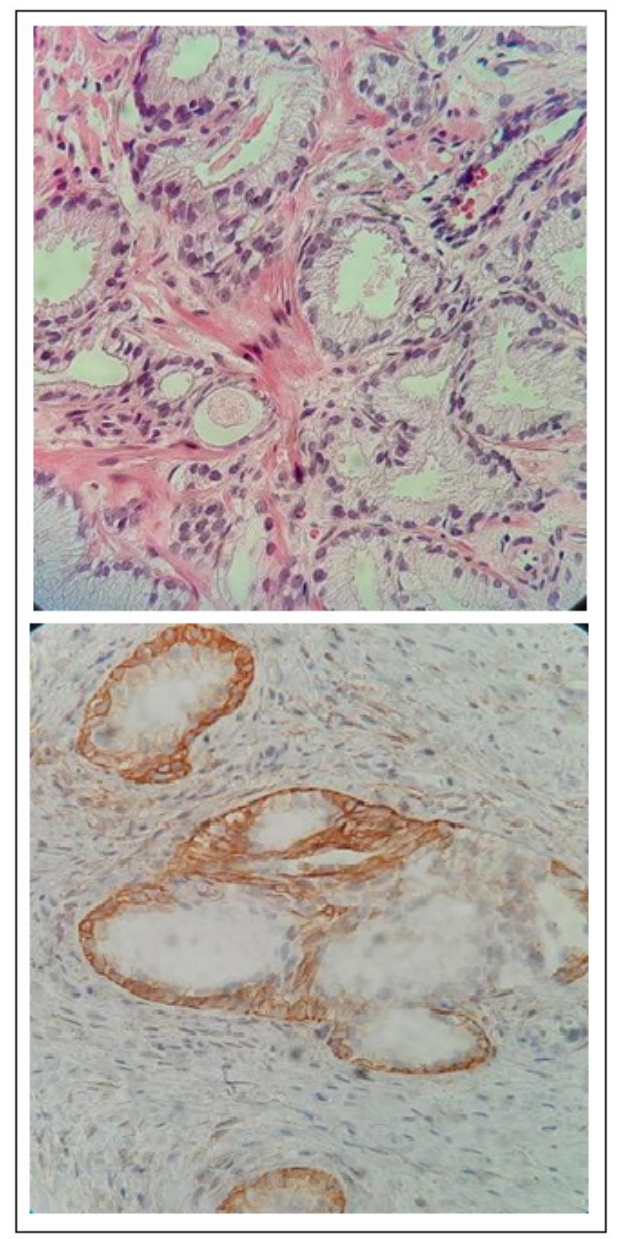

Figure 1. Histological Examination; Upper, prostatic carcinoma on core needle biopsy (H\&E, x400) and Lower, COX-2 staining on prostatic carcinoma (x400). 
Table1. Sequences of the Primers for COX-2 in PCR

\begin{tabular}{llc}
\hline Primers & Sequence & TM \\
\hline COX-2-F & 5-ATCATTCACCAGGCAAATTGC-3 & 60.66 \\
COX-2-R & 5-GGCTTCAGCATAAAGCGTTTG-3 & 60.69 \\
B-ACTIN-F & 5-GCTCCTCCTGAGCGCAAGT-3 & 61.6 \\
B-ACTIN-R & 5-TCGTCATACTCCTGCTTGCTGAT-3 & 61.96 \\
\hline
\end{tabular}

Table 2. Cyclooxygenase-2 (COX-2) Mean Expression Fold Change in Prostatic Carcinoma and Normal Tissue

\begin{tabular}{lcccc}
\hline Gene & $\begin{array}{c}\text { Prostatic carcinoma } \\
\text { Mean } \pm \text { SD }\end{array}$ & $\begin{array}{c}\text { Normal tissue } \\
\text { Mean } \pm \text { SD }\end{array}$ & Fold change & P-value \\
\hline COX-2 & $5.52 \pm 0.42$ & $2.36 \pm 0.8$ & 2.3 & 0.004 \\
\hline
\end{tabular}

$\mathrm{P}<0.05$ have considerate as significant.

increase in mRNA expression when compared to normal prostatic tissue.

In comparison between two method including IHC staining and PCR exhibited IHC staining was more sensitive than PCR (P-Value: $<0.05$ ). So, for COX-2 expression detection, IHC staining is useful even in small samples. Because PCR cannot detect at least gene expression and expression should be more than detection limit of PCR. Efficacy of PCR in detecting gene proliferation in samples with IHC staining grade of +3 was $100 \%$ and in the case of IHC staining grade of +2 was about $50 \%$ (Figure 3). PCR was able to detect gene

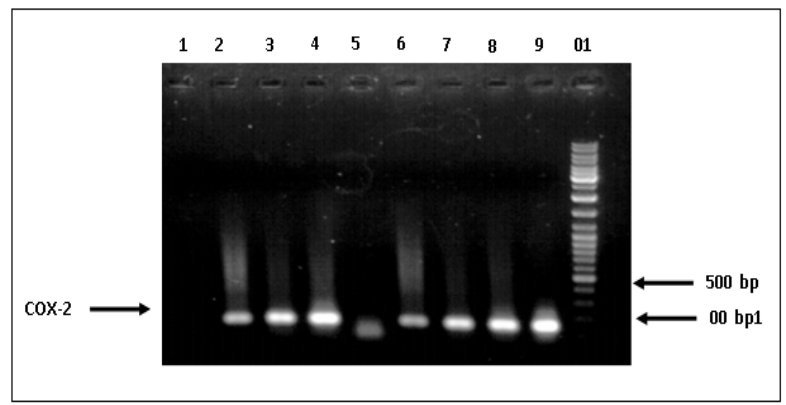

Figure 2. The COX-2 Gene Expression in PC and Benign Tissue by PCR. Columns number 1-4 are normal tissue, columns number 6-9 are PC (IHC grade +3 ), column number 5 is negative control. Non-specific bands show interfering factors.

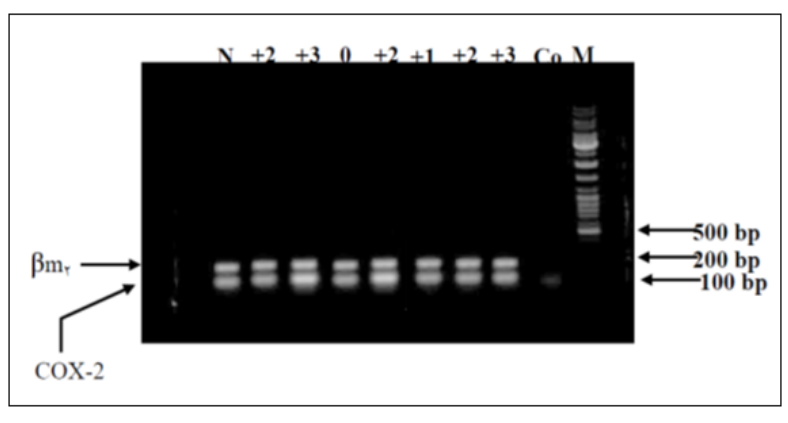

Figure 3. The COX-2 Gene Expression in PC by PCR According to IHC Grading. IHC grades are upper picture, $\mathrm{N}$ is normal tissue, $\mathrm{M}$ is $100-1000 \mathrm{bp}$ marker and Co is negative control. proliferation in all cases with high COX-2 expression in IHC staining of tumor samples. But between COX-2 expression detection by two method and Gleason score of PC was not any relationship (P-Value $>0.5$ ).

\section{Discussion}

For several decades, the absence of exact diagnostic and prognostic biomarkers for PC has interested investigators to search for new specific markers to precisely predict recurrent and metastatic PC [13]. Cohesive scientific data from molecular studies supports the hypothesis that abnormal induction of COX-2 and up-regulation of the prostaglandin cascade show a important part in carcinogenesis, and equally, blockade of the process has strong probable for cancer prevention and therapy [14]. Various studies recommend a role for COX-2 in carcinogenesis. However, little is identified about the role sequence variation within the COX-2 gene plays in prostate cancer risk. Panguluri et al. study suggests that variation of the $\mathrm{COX}-2$ promoter may influence the risk and development of prostate cancer [15]. COX-2 is expressed in numerous types of normal epithelial tissues, comprising normal prostate glands in man. Prior research has established that COX-2 expression is maintained during malignant transformation and is expressed in PC [16] which is similar our study and is proved as diagnostic marker. Up-regulated COX-2 may play a role in inducing cell proliferation, differentiation, apoptosis, or angiogenesis [17]. COX-2 overexpression might lead to local persistence of disease and, consequently, more incidence of distant metastasis. Alternatively, COX-2 overexpression might be a risk factor for early metastasis, which might be supported by the conclusion that COX-2 overexpression is accompanying by angiogenesis (18) but in our study is not association between COX-2 expression and tumor grade and Gleason score. So, we couldn't use it as prognostic factor. Multiple studies have revealed increased expression of COX2 in prostate tumors only, although one study reported overexpression not in tumor tissue but rather in proliferative inflammatory atrophy, a putative precursor lesion of prostate cancer [19] which was according to a number of studies recommend that COX-2 expression is not only an initial happening in the carcinogenesis, but is obligatory during the whole 
evolutionary process of cancer growth and development [20]. A study by Yoshimura et al. showed the amount and intensity of immunoreactive COX-2 in tumor cells was statistically much greater than those of cells from benign hyperplasia. These outcomes were further confirmed by mRNA analysis, where enhanced expression of COX-2 was detected in prostate cancer tissues. These results lead to the conclusion that human prostate carcinoma cells generated COX-2, and that COX-2 might play an significant role in the proliferation of prostate carcinoma cells which is confirmed by our study [21]. Richardsen et al. study showed high expression of COX-2 was correlated with death from PC [22]. These documents establish that COX-2, are expressed in all stages of human prostate carcinogenesis [23]. Brian L et al. study showed Gleason score, preoperative serum prostatic specific antigen (PSA) level, extraprostatic extension, surgical margin, seminal vesicle invasion, and high COX-2 expression were important predictors of biochemical recurrence [24]. The positive rates of COX-2 were higher in high Gleason score group than those in low Gleason score group. So, the high expressions of COX-2 in PC may be related to tumor pathological grade [25] but we couldn't establish it in our study. Also, Thibaut et al. study proposed increased levels of this protein in the tumors were all considerably related with higher Gleason scores and pathologic stages, tumor extraprostatic extension and loss of differentiation [26] which in our study only COX-2 expression was seen in neoplastic tissue but was not seen in normal tissue. We couldn't introduce COX-2 as prognostic factor. Also, some study suggested that overexpression of COX-2 links with T3-T4 stages of PC [27]. Furthermore, patients with high-COX-2 expression revealed lower disease-free and overall survival rates than those with low-COX-2 expression [28]. So, COX2 inhibitors are currently being used in clinical trials for the treatment of PC [29]. This facts suggest that COX-2 is over-expressed in prostate cancer and COX-2 inhibitors may be valuable in combination chemotherapy or chemoprevention for prostate cancer [30]. Therefore, COX-2 might be a potential therapy target for $\mathrm{PC}$ and work as a diagnostic and prognostic factor for $\mathrm{PC}$ patients.

In conclusion, the expression of COX-2 protein by IHC and PCR in our study offers the valuable diagnostic information but is not well associated with histological grade of prostatic carcinoma in biopsies. This may be in part due to the relatively small sample size and various factors such as patient characteristics or procedure specifications.

\section{References}

1. De Marzo AM, Meeker AK, Zha S, Luo J, Nakayama M, Platz EA, Isaacs WB, Nelson WG. Human prostate cancer precursors and pathobiology. Urology. 2003 Nov;62(5):5562. https://doi.org/10.1016/j.urology.2003.09.053

2. Sandhu JS. Prostate cancer and chronic prostatitis. Current Urology Reports. 2008 07;9(4):328-332. https://doi. org/10.1007/s11934-008-0056-6

3. Aparicio Gallego G, Díaz Prado S, Jiménez Fonseca P, García Campelo R, Cassinello Espinosa J, Antón Aparicio
LM. Cyclooxygenase-2 (COX-2): a molecular target in prostate cancer. Clinical and Translational Oncology. 2007 Nov;9(11):694-702. https://doi.org/10.1007/s12094-0070126-0

4. Yoshimura R, Sano H, Masuda C, Kawamura M, Tsubouchi Y, Chargui J, et al. Expression of cyclooxygenase-2 in prostate carcinoma. Cancer. 2000;89(3):589-96.

5. Hussain T, Gupta S, Adhami VM, Mukhtar H. Green tea constituent epigallocatechin-3-gallate selectively inhibits COX-2 without affecting COX-1 expression in human prostate carcinoma cells. International Journal of Cancer. 2004;113(4):660-669. https://doi.org/10.1002/ijc.20629

6. Zha S, Gage W, Sauvageot J, Saria E, Putzi M, Ewing C, et al. Cyclooxygenase-2 is up-regulated in proliferative inflammatory atrophy of the prostate, but not in prostate carcinoma. Cancer Research. 2001;61(24):8617-23.

7. Narayanan BA, Narayanan NK, Pttman B, Reddy BS. Adenocarcina of the mouse prostate growth inhibition by celecoxib: Downregulation of transcription factors involved in COX-2 inhibition. The Prostate. 200602 15;66(3):257265. https://doi.org/10.1002/pros.20331

8. Rao DS, Gui D, Koski ME, Popoviciu LM, Wang H, Reiter RE, Said JW. An Inverse Relation Between COX-2 and E-cadherin Expression Correlates With Aggressive Histologic Features in Prostate Cancer. Applied Immunohistochemistry \& Molecular Morphology. 2006 Dec;14(4):375-383. https://doi.org/10.1097/01. pai.0000210417.61117.6c

9. L'Eplattenier HF, Lai CL, Ham R, Mol J, Sluijs F, Teske E. Regulation of COX-2 Expression in Canine Prostate Carcinoma: Increased COX-2 Expression is Not Related to Inflammation. Journal of Veterinary Internal Medicine. 2007 07;21(4):776-782. https://doi. org/10.1111/j.1939-1676.2007.tb03021.x

10. Epstein JI, Egevad L, Amin MB, Delahunt B, Srigley JR, Humphrey PA. The 2014 International Society of Urological Pathology (ISUP) Consensus Conference on Gleason Grading of Prostatic Carcinoma. American Journal of Surgical Pathology. 2016 02;40(2):244-252. https://doi. org/10.1097/pas.0000000000000530

11. Hayes A, Scase T, Miller J, Murphy S, Sparkes A, Adams V. COX-1 and COX-2 Expression in Feline Oral Squamous Cell Carcinoma. Journal of Comparative Pathology. 2006 08;135(2-3):93-99. https://doi.org/10.1016/j. jсpa.2006.06.001

12. Gupta S, Srivastava M, Ahmad N, Bostwick DG, Mukhtar H. Over-expression of cyclooxygenase-2 in human prostate adenocarcinoma. The Prostate. 2000 01 01;42(1):73-78. https://doi.org/10.1002/(sici)10970045(20000101)42:1<73::aid-pros9>3.0.co;2-g

13. Lee K, Kim S, Park W, Park B, Joo J, Joung J, Seo H, Chung J. PSCA, Cox-2, and Ki-67 are independent, predictive markers of biochemical recurrence in clinically localized prostate cancer: a retrospective study. Asian Journal of Andrology. 2017;19(4):458. https://doi.org/10.4103/1008682x. 180798

14. Harris R. Cyclooxygenase-2 (cox-2) and the inflammogenesis of cancer. Inflammation in the Pathogenesis of Chronic Diseases: Springer. 2007;:93-126. https://doi.org/10.1007/14020-5688-5 4

15. Panguluri RC. COX-2 gene promoter haplotypes and prostate cancer risk. Carcinogenesis. 200402 04;25(6):961-966. https://doi.org/10.1093/carcin/bgh100

16. Sorenmo KU, Goldschmidt MH, Shofer FS, Goldkamp C, Ferracone J. Evaluation of cyclooxygenase-1 and cyclooxygenase- 2 expression and the effect of 
cyclooxygenase inhibitors in canine prostatic carcinoma. Veterinary and Comparative Oncology. 2004 03;2(1):13-23. https://doi.org/10.1111/j.1476-5810.2004.00035.x

17. Wang W, Bergh A, Damber J. Cyclooxygenase-2 Expression Correlates with Local Chronic Inflammation and Tumor Neovascularization in Human Prostate Cancer. Clinical Cancer Research. 2005 05 01;11(9):3250-3256. https://doi. org/10.1158/1078-0432.ccr-04-2405

18. Khor L, Bae K, Pollack A, Hammond MEH, Grignon DJ, Venkatesan VM, Rosenthal SA, Ritter MA, Sandler HM, Hanks GE, Shipley WU, Dicker AP. COX-2 expression predicts prostate-cancer outcome: analysis of data from the RTOG 92-02 trial. The Lancet Oncology. 2007 Oct;8(10):912-920. https://doi.org/10.1016/s14702045(07)70280-2

19. Cheng I, Liu X, Plummer SJ, Krumroy LM, Casey G, Witte JS. COX2 genetic variation, NSAIDs, and advanced prostate cancer risk. British Journal of Cancer. 200707 03;97(4):557561. https://doi.org/10.1038/sj.bjc.6603874

20. Inoue T, Anai S, Onishi S, Miyake M, Tanaka N, Hirayama A, Fujimoto K, Hirao Y. Inhibition of COX-2 expression by topical diclofenac enhanced radiation sensitivity via enhancement of TRAIL in human prostate adenocarcinoma xenograft model. BMC Urology. 201301 05;13(1). https:// doi.org/10.1186/1471-2490-13-1

21. Hussain T, Gupta S, Mukhtar H. Cyclooxygenase-2 and prostate carcinogenesis. Cancer Letters. 2003 03;191(2):125135. https://doi.org/10.1016/s0304-3835(02)00524-4

22. Richardsen E, Uglehus RD, Due J, Busch C, Busund L. COX-2 is overexpressed in primary prostate cancer with metastatic potential and may predict survival. A comparison study between COX-2, TGF- $\beta$, IL-10 and Ki67. Cancer Epidemiology. 2010 06;34(3):316-322. https://doi. org/10.1016/j.canep.2010.03.019

23. Kirschenbaum A, Klausner AP, Lee R, Unger P, Yao S, Liu X, Levine AC. Expression of Cyclooxygenase-1 and Cyclooxygenase- 2 in the human prostate. Urology. 2000 Oct;56(4):671-676. https://doi.org/10.1016/s00904295(00)00674-9

24. Cohen BL, Gomez P, Omori Y, Duncan RC, Civantos F, Soloway MS, Lokeshwar VB, Lokeshwar BL. Cyclooxygenase-2 (cox-2) expression is an independent predictor of prostate cancer recurrence. International Journal of Cancer. 2006;119(5):1082-1087. https://doi.org/10.1002/ ijc. 21749

25. LIU J, ZHANG W. Expression of COX-2 and VEGF in human prostate cancer and their relationship with Gleason score [J]. Journal of Clinical Medicine in Practice. 2007;1.

26. Dassesse T, de Leval X, de Leval L, Pirotte B, Castronovo V, Waltregny D. Activation of the Thromboxane A2 Pathway in Human Prostate Cancer Correlates with Tumor Gleason Score and Pathologic Stage. European Urology. 2006 Nov;50(5):1021-1031. https://doi.org/10.1016/j. eururo.2006.01.036

27. Shao N, Feng N, Wang Y, Mi Y, Li T, Hua L. Systematic review and meta-analysis of COX-2 expression and polymorphisms in prostate cancer. Molecular Biology Reports. 2012 Oct 07;39(12):10997-11004. https://doi. org/10.1007/s11033-012-2001-5

28. Bin W, He W, Feng Z, Xiangdong L, Yong C, Lele K, Hongbin $\mathrm{Z}$, Honglin G. Prognostic relevance of cyclooxygenase-2 (COX-2) expression in Chinese patients with prostate cancer. Acta Histochemica. 2011 02;113(2):131-136. https://doi. org/10.1016/j.acthis.2009.09.004

29. Edwards J, Mukherjee R, Munro A, Wells A, Almushatat A, Bartlett J. HER2 and COX2 expression in human prostate cancer. European Journal of Cancer. 2004 01;40(1):50-55. https://doi.org/10.1016/j.ejca.2003.08.010

30. Lee L, Pan C, Cheng C, Chi C, Liu T, Pan C, et al. Expression of cyclooxygenase- 2 in prostate adenocarcinoma and benign prostatic hyperplasia. Anticancer research.

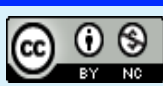

This work is licensed under a Creative Commons AttributionNon Commercial 4.0 International License. 